\title{
Experimental Study of Sintered Friction Material with Coconut Fiber for Brake Pads
}

\author{
CAMELIA PINCA BRETOTEAN ${ }^{1 *}$, ANDREI LUCIAN CRACIUN², ANA JOSAN ${ }^{1}$, ERIKA ARDELEAN ${ }^{1}$ \\ 'Univesity Politehnica Timisoara, Faculty Engineering of Hunedoara, 5 Revolutiei Str., 331128, Hunedoara, Romania \\ ${ }^{2}$ S.C. Alan Transimpex, 67E Garii Str., 337532, Mintia, Romania
}

\begin{abstract}
The paper presents the laboratory experiments and the results obtained regarding the production and characterization of composite materials with coconut fiber for the manufacture of brake pads for small vehicles and medium performances. The experimental research of composite material with organic components determined the influence of some material factors and parameters of the sintering regime on the physico-mechanical characteristics of the tested samples. Knowledge of these characteristics offers the possibility of pertinent appraisals regarding the behaviour of the composite materials intended for used in brake pads applications. Materials with the best features will be selected to determine the functional characteristics of friction and wear.
\end{abstract}

Keywords: brake pad, composite, organic materials, coconut fiber

Current road safety requirements call for the development of new technical solutions for the main components of the vehicle. Their technical performances depend on the physical and mechanical characteristics of the materials which they are made [1,2]. Traditional materials used in automotive design have been studied over the time, so today is know their characteristics, their advantages and disadvantages. Technological issues that can not be adequately by using these materials have determined researchers in the field of automotives to look fornew materials to replace the classic ones $[3,4]$. On the other side, due to the need for a sustainable resource of raw materials, as well as environmental problems, automotive manufacturers are always looking for new materials, especially composites, with law impact on the environment and human health. Because of these problems, the world is focusing on the use of organic composite materials that are appreciated in areas where material weight plays an important role, such as automotives [5].

Organic fibers used to reinforce composite materials can be obtained from a wide variety of plants [6, 7]: cereal strains (wheat, barley, rice, rye), textile plants (in, hemp, rapeseed, cotton), plants with hard fibers (cane, rush, rape, coconut, bamboo, banana, sisal etc.). A great disadvantage of organic fibers is the differences in anatomical and chemical structure, which determines physico-chemical properties with large variations from one species to another, sometimes even within the same species, due to vegetation and microclimate conditions [8].

Different papers have been reported in the scientific literature on the use of organic fibers in the production of composite materials, such as: pineapple, sisal, coconut shell, jute, palm, cotton, rice husks, bamboo, wood [2, 914]. Composite materials with coconut fiber have a wide range of applicability in countries such as Malaysia, Indonesia, Thailand, Sri Lanka. They being used as building materials, marine ropes, fishing devices, furniture, household appliances [10]. Given the broad scope of applicability and because they are biodegradable and abundantresources in these geographical areas, their study has been the subject of more research, which have shown that this organic fiber has properties that approve its application in use as a friction material, due to its high strength, low weight and superior properties to the products obtained $[2,9,10]$. In this work will be produced in the laboratory and characterize four recipes of composite materials with coconut fiber, designed to make the brake pads for small vehicles and average performance. In order to validate the results obtained in this paper we have chosen some scientific papers which have obtained and characterized composite materials with organic fiber material, $[9-13,15,16]$.

\section{Experimental part}

The experimental research program comprises the following stages [1]: obtaining composite materials in the laboratory, determination of physico-mechanical characteristics, analysis of surface morphology, analysis and interpretation of the results.

The production in laboratory of organic fiber composite materials implied the establishment of the recipes and the parameters of the sintering technology. Achieving these goals was based on sound documentation in the scientific literature and numerous attempts and experiments. Sintering technology has been improved from near to near, from one sample to another, trying to solve the shortcomings and identify the causes that led to obtained inadequate samples.

In order to establish the recipes presented in this paper, we used a mixture of raw materials made of aluminium, graphite, zirconium oxide, silicon carbide, titanium oxide, aluminium oxide, hexametyltetramine, phenolic resin (Râonov type) and coconutfibre. The laboratory production of organic composite materials for brake pads is based on powder metallurgy. The main reason for use powder metallurgy is to obtain an increased homogeneity of the components $[1,9-13,15-17]$. The four recipes can be divided into two families of composite materials due to the similar composition of the components. The first family of composite materials (F1) contains titanium oxide and the second (F2) contains the same amount of aluminium oxide. The chemical composition of composite materials in F1 family is shown in table 1, and in table 2 for F2 family.

The raw materials were milled, sorted by granulometric classes, weighed, compacted and then subjected to the

\footnotetext{
*camelia.bretotean@fih.upt.ro; Phone: 0732165956
} 
Table 1

CHEMICAL COMPOSITION OF COMPOSITE MATERIALS BELONGING

TO THE F1 FAMILY

\begin{tabular}{|c|c|c|c|c|c|c|c|c|}
\hline Samples & $\begin{array}{c}\text { Aluminium } \\
{[\%]}\end{array}$ & $\begin{array}{c}\text { Grafite } \\
{[\%]}\end{array}$ & $\begin{array}{c}\text { Zirconia } \\
\text { oxide } \\
{[\%]}\end{array}$ & $\begin{array}{c}\text { Silicon } \\
\text { carbide } \\
{[\%]}\end{array}$ & $\begin{array}{c}\text { Titan } \\
\text { oxide } \\
{[\%]}\end{array}$ & $\begin{array}{c}\text { Phenolic } \\
\text { resin } \\
{[\%]}\end{array}$ & $\begin{array}{c}\text { Hexametylt } \\
\text { etramine } \\
{[\%]}\end{array}$ & $\begin{array}{c}\text { Coconut } \\
\text { fibre } \\
{[\%]}\end{array}$ \\
\hline $\mathrm{C} 1$ & 20 & 5 & 2 & 11 & 11 & 40 & 6 & 5 \\
\hline $\mathrm{C} 2$ & 15 & 5 & 2 & 11 & 11 & 40 & 6 & 10 \\
\hline
\end{tabular}

Table 2

CHEMICAL COMPOSITION OF COMPOSITE MATERIALS BELONGING TO THE F2 FAMILY

\begin{tabular}{|c|c|c|c|c|c|c|c|c|}
\hline Samples & $\begin{array}{c}\text { Aluminium } \\
{[\%]}\end{array}$ & $\begin{array}{c}\text { Grafite } \\
{[\%]}\end{array}$ & $\begin{array}{c}\text { Zirconia } \\
\text { oxide } \\
{[\%]}\end{array}$ & $\begin{array}{c}\text { Silicon } \\
\text { carbide } \\
{[\%]}\end{array}$ & $\begin{array}{c}\text { Aluminium } \\
\text { oxide } \\
{[\%]}\end{array}$ & $\begin{array}{c}\text { Phenolic } \\
\text { resin } \\
{[\%]}\end{array}$ & $\begin{array}{c}\text { Hexametylt } \\
\text { etramine } \\
{[\%]}\end{array}$ & $\begin{array}{c}\text { Coconut } \\
\text { fibre } \\
{[\%]}\end{array}$ \\
\hline C3 & 20 & 5 & 2 & 11 & 11 & 40 & 6 & 5 \\
\hline C4 & 15 & 5 & 2 & 11 & 11 & 40 & 6 & 10 \\
\hline
\end{tabular}

sintering process. Their mixing was carried out with a mechanical stirrer at $2500 \mathrm{rpm}$ for $25 \mathrm{~min}$. At the end of the mixing process, the composition had the appearance of a viscous paste and was placed in a metal mold for sintering. The mold-sample assembly was hydraulic pressed with a force of $15 \mathrm{KN}$ and placed in a $3.6 \mathrm{KW}$ electric power furnace at $275^{\circ} \mathrm{C}$ for $45 \mathrm{~min}$. At $15 \mathrm{~min}$ from starting heating, the mold-sample assembly was extracted from the furnace and pressed on a hydraulic press with a force of $20 \mathrm{KN}$, after which the furnace temperature was reduced to $200^{\circ} \mathrm{C}$, where the sample was maintained for 4 h. Cooling was carried out in two stages, in the oven at 100 ${ }^{\circ} \mathrm{C}$ for $8 \mathrm{~h}$ and in air, at ambient temperature for $48 \mathrm{~h}$.

Figure 1 shows the samples obtained after the four recipes at the end of the sintering process. These were analyzed from the point of view of the physico-mechanical characteristics, taking samples of each composite material in accordance with the standards in effect [1].

\section{Results and discussions}

Analyzing the samples obtained in terms of compactness, integrity, elasticity and appearance at the extraction from the mould, the following conclusions could be drawn: all samples preserved their integrity when were extracted from the mould; the homogenization and solidification of the constituents show that the order of the operations for sintering process is good, all samples have a smooth surface, a completely circular geometric shape, appropriate hardness and consistency and the hot and cold compression force applied led to an efficient compaction of the material. So, all samples are considered successful and can be used for sampling, required to characterize the composite materials produced in laboratory.

Figure 2 shows the densities obtained for the composite materials produced in laboratory, using the displaced liquid volume method [ $1,9-13,15]$. It can be seen that the density values for the two families of composites are relatively low compared to the densities of the metals $[1,9]$. In both families of composite materials, sample densities decreased with increasing coconut fiber, because as the amount of filler has increased, the amount of metal in the recipe has decreased. Similar conclusions have been obtained in $[1,9,11]$. Samples C1 and C2 have higher densities than $\mathrm{C} 3$ respectively $\mathrm{C} 4$ due to their titanium composition. Titanium has a higher density than aluminum [1].

Figure 3 shows the comparative results of the porosity in oil and water obtained for C1-C4 samples, according to the standard JIS D 4418: $1996[1,9-11]$. The values obtained for porosity are relatively small. This thing can be attributed to the increase in the bond between the binder (phenolic resin) and coconut fiber (filler) due to proper homogenization of the constituents. The results obtained are comparable to those in the literature [9-13]. Porosity has an important role in automotive brake pads. The function of porosity is to absorb energy and heat, which is

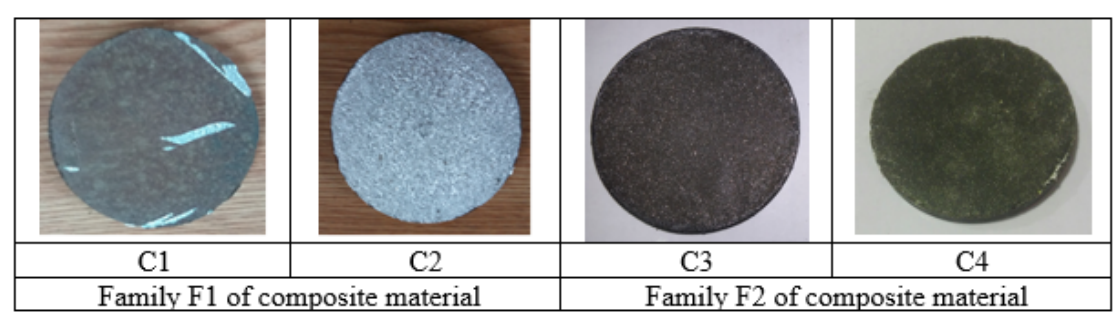

Fig.1 Samples obtained from the four recipes

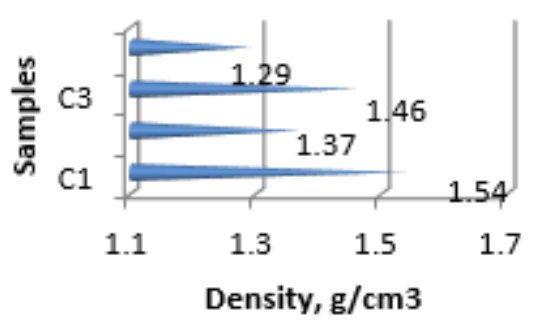

Fig.2 Comparative density analysis

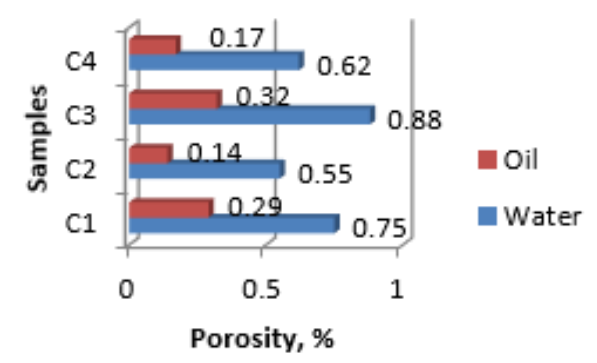

Fig.3 Comparative analysis of porosity in water and oil 
very important for effectiveness of the brake system. Theoretically, lower porosity will results in higher friction coefficient and wear rate due to higher contact areas between the mating surfaces [9].

Figure 4 shows the results obtained in determining the hardness by the Brinell method for the analyzed samples [1]. The variable content of coconut fiber and aluminum determines different values of samples hardness. The highesthardness values were obtained for $\mathrm{C} 2$ and $\mathrm{C} 4$, both of them were made with $10 \%$ coconut fiber. These values are favorable compared to other composites materials from similar researches [9-13].

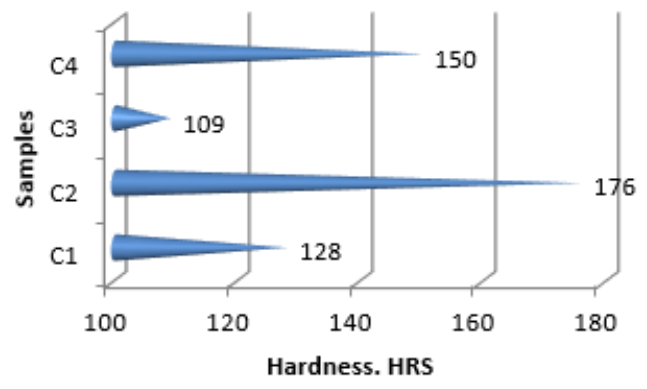

Fig.4 Comparative analysis of hardness

The determination of the compressive strength of the samples was carried outon a universal mechanical testing machine from the Laboratory of Resistance of Materials to the Faculty of Engineering in Hunedoara. The compression test was performed on a sample of 15 parallelepiped samples. Table 3 shows the mean values obtained from the compressive tests.
Table 3 shows that the compressive strength of composite $\mathrm{C} 1$ is lower than composite $\mathrm{C} 2$ and can withstand high stresses. It can be noticed that even in the case of the F2 family of composite materials, the sample made with 10\% coconut fiber shows the highest breaking strength. Samples with the highest amount of coconut fiber $(10 \%)$ have the highest compressive strength. This is explained by the fact that the organic fiber particles have evenly distributed over the aluminum matrix, making corresponding interference between them, and under deformation conditions a corresponding displacement of the organic fibers through the matrix $[1,10,11]$. The compressive strength and the longitudinal elastic modulus increases with the increase in the amount of coconut fiber. Similar conclusions being reached also in [9].

The surface morphology of the samples produced was analyzed using SEM microscopy and EDX analysis [1]. Figure 5 shows SEM images for C1-4 samples. The material particles have different sizes, but are uniformly dispersed in the matrix.

Also, the coconut fiber particles are uniformly distributed through the binder by providing a suitable interface between the filler material and the aluminum matrix [10]. Table 4 presents EDX analysis results.

The carbon element is dominant in the EDX analysis, with an important contribution to increasing the hardness of the samples. This explain by the fact that organic materials such as coconut fiber through the sintering process are thermally oxidized and carbonized, thus creating carbon phases, with an important role in increasing the hardness [10]. Appropriate homogeneity of the samples, the particle size of the particles and their

Table 3

AVERAGE VALUES OF MECHANICAL COMPRESSION CHARACTERISTICS

\begin{tabular}{|c|c|c|c|c|}
\hline \multirow[t]{2}{*}{ Feature } & \multicolumn{2}{|c|}{$\begin{array}{c}\text { Family F1 of composite } \\
\text { material }\end{array}$} & \multicolumn{2}{|c|}{ Family F2 of composite material } \\
\hline & C1 & $\mathrm{C} 2$ & $\mathrm{C} 3$ & $\mathrm{C} 4$ \\
\hline Breaking force $[\mathrm{N}]$ & 11886 & 14577 & 8280 & 12992 \\
\hline Maximum normal tension $\left[\mathrm{N} / \mathrm{mm}^{2}\right]$ & -27.6141 & -35.7912 & -25.6162 & -33.0730 \\
\hline Shortening of sample [mm] & 0.016 & 0.018 & 0.015 & 0.017 \\
\hline $\begin{array}{l}\text { Maximum deformation at maximum load force } \\
\varepsilon_{\text {med }}[\%]\end{array}$ & 0.105 & 0.116 & 0.132 & 0.126 \\
\hline Modulus of longitudinal elasticity $E\left[\mathrm{~N} / \mathrm{mm}^{2}\right]$ & 262999.142 & 32537.454 & 19406.212 & 26248.412 \\
\hline
\end{tabular}

\begin{tabular}{|c|c|c|c|c|}
\hline Element & C1 (\%) & C2 (\%) & C3 (\%) & C4 (\%) \\
\hline $\mathrm{C}$ & 43.12 & 47.72 & 42.67 & 46.89 \\
\hline $\mathrm{Al}$ & 21.33 & 18.32 & 34.36 & 30.52 \\
\hline $\mathrm{Ti}$ & 22.32 & 20.35 & - & - \\
\hline $\mathrm{O}$ & 9.12 & 9.46 & 18.69 & 17.82 \\
\hline $\mathrm{Na}$ & 0.67 & 0.79 & 0.84 & 0.69 \\
\hline $\mathrm{Si}$ & 1.89 & 1.58 & 1.71 & 1.67 \\
\hline $\mathrm{Fe}$ & 1.10 & 1.23 & 1.14 & 1.56 \\
\hline $\mathrm{Zr}$ & 0.45 & 0.55 & 0.59 & 0.85 \\
\hline Total & 100.00 & 100.00 & 100.00 & 100.0 \\
\hline
\end{tabular}

Table 4

RESULTS OF EDX ANALYSIS FOR ORGANIC COMPOUND COMPOSITE MATERIALS

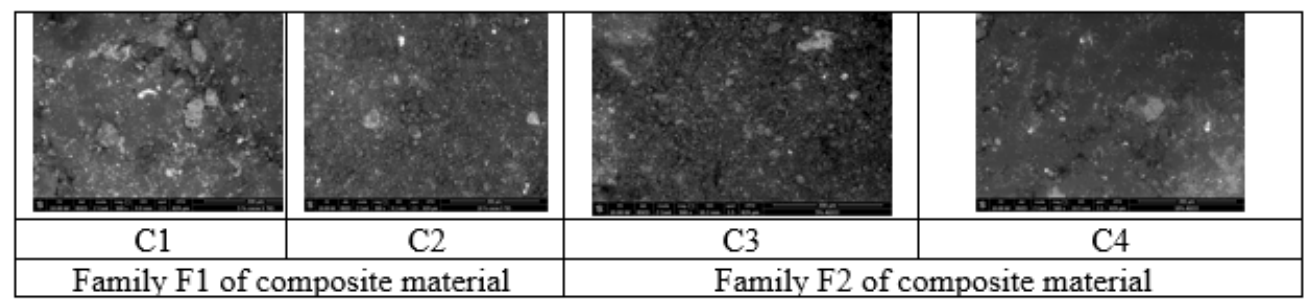

Fig.5 SEM images for organic materials obtained in the laboratory 
distribution determined the corresponding values for hardness and increased compressive strength [1]. In the examined samples there is an amount of iron, titanium respectively aluminum that is beneficial to the destination of the organic composite materials produced because the use of the metallic ingredients in the recipes leads to the improvement of the properties of these materials [1,18, 19]. The EDX analysis showed a relatively good combination of the constituents, without changes in their proportion.

\section{Conclusions}

As a result of the experiments we made the following conclusions:

- the density of organic composite materials produced increases with the increase in the amount of coconut fibre; - low porosity, both in water and in oil was determined by the proper homogenization of the recipe components; - the hardness, compressive strength and longitudinal elasticity modulus increase with the increase in the amount of coconut fibre;

- surface morphology analysis showed that there were no changes in the proportion of components after sintering and there is a relatively good combination between them;

- obtaining superior physical and mechanical characteristics for the samples is due: appropriate homogenization of the constituents of the recipes, particle size of the material, distribution of filler material through the matrix, an optimal proportion of the amount of metal and other components, parameters of the sintering regime and the value of the applied pressing force;

- the structural integrity of composite materials provides superior physical and mechanical properties;

- the inconvenience of producing the composite materials analyzed in this paper is the relatively high price of the raw material, coconut being an exotic fruit;

- composite materials with the best physico-mechanical characteristics are C2 and C4, which have $10 \%$ coconut fiber.

The most suitable composite material for brake pads can not be selected solely on the basis of the assessment of the physico-mechanical characteristics. These can only be used to control the quality of recipes developed in the manufacturing process. Conversely, the physical and mechanical properties of the same recipes indicate that the composite material production process is under control [1]. Materials with the best physico-mechanical characteristics ( $\mathrm{C} 2$ and $\mathrm{C} 4$ ) will be selected to determine the functional characteristics of friction and wear.

\section{References}

1.CRACIUN, A., Research on the use of composite materials in vehicle braking systems, PhD Thesis, 2018

2.SOCALICI, A., ARDELEAN, E., PASCU, E., PUTAN, V., Friction and Wear Behaviour of Composite Materials Containing Organic Components, Mat. Plast., 54, no.2, 2017, p.269-273
3. *** Scientific report PN-II-ID-PCE-2012-4-0104, 2016

4.VASILESCU, M.D., FLESER, T., Influence of Technological Parameters on the Dimension of GEAR, Parts Generated with PLA Matherial by FDM 3D Printing, Mat. Plast., 55, no.2, 2018, p.247-251

5.NICOLAE, O.,I., Impact of composite materials used in construction on the environment, PhD Thesis, 2013

6.WEINTRAUB, M., Brake additives consultant. Private communication, 1998

7.TERCIU, O., M., CURTU, C., CERBU, M., STANCIU, M.,D., Traction testing of lignocellulosic composites with applications in the automotive industry, Bul. AGIR 1, 2012, p.40

8.VIJAY. R., JEESJ . M., SAIBALAJ I, M.A., THIYAGARAJ AN V., Optimization of Tribological Properties of Nonasbestos Brake Pad Material by Using Steel Wool, Advances in Tribology 2013165859

9.MALEQUE M.A., ATIQAH, A., TALIB, R.J., ZAHURIN, H. New natural fibre reinforced aluminium composite for automotive brake pad, International Journal of Mechanical and Materials Engineering, 7, no.2, 2012, p.166

10.SUTIKNO , M., MARWOTO, P., RUSTAD, S. The mechanical properties of carbonized coconut char pow der-based friction materials, www.elsevier.com/locate/carbon 48, 2010, p.3616

11.ADEYEMI, I.,O., ADEMOH, N., OKECHUKWU, O.M. Development and Assessment of Composite Brake Pad Using Pulverized Cocoa Beans Shells filler, International J ournal of Materials Science and Applications, 5, no.2, 2016, p.66

12.EDOKPIA, R.,O., AIGBODION, V.S. , OBIORAH, O.B. , ATUANYA, C.U., Evaluation of the Properties of Ecofriendly Brake Pad Using Egg Shell Particles-Gum Arabic, ScienceDirect, Elsevier. B. V. DOI: 10.1016/ j.rinp.2014.06.003

13.ADEMOH, A. , NUHU, I., ADEYEMI I., OLABISI I., Development and Evaluation of Maize Husks (Asbestos-Free) Based Brake Pad, Industrial Engineering Letters 5, no. 2, 2015, p. 67

14.STEFANESCU, V., BOBOC, A., COJAN, A., BOSOANCA, R., MUNTENITA, C., BUNEA, M., The Thermal Behavior of Hybrid Fabric Reinforced Composites with Stratified Filled Epoxy Matrix, Mat. Plast. 55, no.2, 2018, p.161-166

15.LAWAL, S.,S., BALA, K.,C., ALEGBEDE, A.T. Development and production of brake pad from sawdust composite, Leonardo J ournal of Sciences, 30, 2017, p.47

16.SAPUAN, S., M., HARIMI, H, MALEQUE, M., A., Mecanical properties of epoxy/ coconut shell filler particle composites, Arabian J ournal for Science and Engineering, 28, no. 2B, 2003, p.171-181

17.BORDEASU, I., MITELEA, I., LAZAR, I., MICU, L. M., KARANCSI, 0., Cavitation Erosion Behaviour of Cooper Base Layers Deposited by HVOF Thermal Spraying, Rev. Chim. (Bucharest), 68, no. 12, 2107, p. 2914

18.BEJ , A., BORDEASU, I., MILOS, T., BADARAU, R., Considerations Concerning the Mechanical Strength of Wind Turbine Blades made of Fiberglass Reinforced Polyester, Mat. Plast. 49, no.3, 2012, p. 212-218 19.BORDEASU, I., MICU, L. M., MITELEA, I., UTU, I., D., PIRVULESCU, L. D., SIRBU, N. A., Cavitation Erosion of HVOF Metal-ceramic Composite Coatings Deposited onto Duplex Stainless Steel Substrate, Mat. Plast., 53, no.4, 2016, p.781-786

Manuscript received: 7.06 .2018 